Simbiosis Mutualisme Perpustakaan dengan Media Cetak sebagai Upaya Membudayakan Membaca dan Menulis bagi Masyrakat Muhammad Rohmadi

- Faktor Pengembangan dan Isu dalam Masalah Karier Pustakawan Masriyatun

Menguak Informasi via Alexa.com sebagai Evaluasi Menuju Optimalisasi

- Keberaksesan terhadap Perpustakaan dan Institusinya Wiji Suwarno

Profesionalisme Pustakawan dalam Layanan Informasi SriAnawati

Public Space dan Private Space: Posisi Strategis Perpustakaan dalam Mendukung

Pembelajaran Kolaboratif Purwani Istiana

Mewujudkan World-class Professionalism of Librarians di Era Library Mobile

Yuni Nurjanah

- Tantangan dan Kesiapan Pustakawan di Era Digital Dian Hapsari

Formulasi Strategi Membangun Eksistensi Perpustakaan Perguruan Tinggi

(Studi UPT Perpustakaan UNS Tahun 2015) RiahWiratningsih

Optimalisasi Perpustakaan Desa dalam Rangka Meningkatkan Pendidikan Masyarakat Bambang Hemanto

Optimalisasi Layanan Perpustakaan Perguruan Tinggi melalui Pemanfaatan Social

- Media Networking sebagai Media Komunikasi antara Perpustakaan dan Pemustaka Haryanto

Rekonstruksi Budaya Hukum Masyarakat dalam Pemulihan Pascakonflik Etnis Madura dan Melayu di Kabupaten Sambas 


\section{Jurnal \\ Pustaka Ilmiah \\ Jurnal Ilmiah UPT Perpustakaan UNS}

Jurnal Pustaka Ilmiah (JPI) sebagai media kreasi para pustakawan, guru, dosen, dan praktisi dalam pengembangan profesi secara berkelanjutan. Berbagai ide dan gagasan kreatif menjadi bahan kajian yang diimplementasikan dalam berbagai model pengembangan bahan pustaka, baik cetak maupun online. Kreativitas menjadi akar pengembangan ilmu pengetahuan sepanjang hayat dengan berbagai model pengembangan budaya literasi di perpustakaan. Keindahan dan kecermatan dalam sebuah tulisan ilmiah dan nonilmiah akan dapat direalisasikan secara nyata oleh sumber daya manusia untuk menghasilkan SDM yang unggul dan kreatif dengan membaca dan menulis untuk menyinari dunia. Budaya literasi menjadi upaya untuk pengembangan dan pemberdayaan perpustakaan sebagai pusat sumber belajar untuk mendukung tri dharma perguruan tinggi.

\section{SUSUNAN REDAKSI JURNAL PUSTAKA ILMIAH UPT PERPUSTAKAAN UNS}

Penanggung Jawab

Ketua Redaksi

Wakil Redaksi

Sekretaris

Penyunting Ahli
: Dr. Muhammad Rohmadi, M.Hum.

: Dra. Tri Hardiningtyas, M.Si.

: Haryanto, M.IP.

: Bambang Hermanto, S.Pd., M.IP., Henny Perwitosari, A.Md.

: 1. Dr. Muhammad Rohmadi, M.Hum. (Universitas Sebelas Maret);

2. Drs. Widodo, M.Soc.Sc. (Universitas Sebelas Maret);

3. Drs. Harmawan, M.Lib. (Universitas Sebelas Maret).

: Daryono, S.Sos., M.IP.; RiahWiratningsih, S.S., M.Si., Dinar Puspita Dewi, S.Sos., M.IP.; Sri Utari, S.E.

: Nurul H., A. Md.; Novi Tri Astuti, A.Md.

: Aji Hartono, A. Md.; Agus Sriyono, A.Md.; Aris Suprihadi, S.IP.

\section{DITERBITKAN OLEH UPT PERPUSTAKAAN UNS}

REDAKSI JURNAL PUSTAKA ILMIAH

Alamat: Jl. Ir. Sutami 36A Kentingan, Surakarta 57126

Telp./Fax.: (0271) 654311; email: jurnal.pustaka.ilmiah@gmail.com 


\section{PENGANTAR REDAKSI}

Salam pustaka. Dengan rasa syukur kepada allah swt. Segenap redaksi Jurnal Pustaka Ilmiah (JPI) mengucapkan banyak terima kasih kepada para penulis yang telah berkontribusi untuk penerbitan perdana JPI. Dengan terbitnya JPI ini berarti UPT Perpustakaan UNS telah memiliki media penulisan bagai para pustakawan, dosen, tenaga kependidikan, guru, dan praktisi untuk menuangkan ide dan gagasan kreatifnya secara tertulis.

Dalam penerbitan JPI perdana ini disajikan sepuluh tulisan antara lain: (1) Faktor Pengembangan dan Isu Dalam Masalah Karier Pustakawan (Masriyatun), (2) Menguak Informasi via Alexa.com sebagai Evaluasi Menuju Optimalisasi Keberaksesan terhadap Perpustakaan dan Institusinya (Wiji Suwarno), (3) Profesionalisme Pustakawan dalam Layanan Informasi (Sri Anawati), (4) Public Space dan Private Space: Posisi Strategis Perpustakaan dalam Mendukung Pembelajaran Kolaboratif (Purwani Istiana), (5) Mewujudkan World-class Professionalism of Librarians di Era Library Mobile (Yuni Nurjanah), (6) Tantangan dan Kesiapan Pustakawan di Era Digital (Dian Hapsari), (7) Formulasi Strategi Membangun Eksistensi Perpustakaan Perguruan Tinggi (Studi UPT Perpustakaan UNS Tahun 2015) (Riah Wiratningsih), (8) Optimalisasi Perpustakaan Desa dalam Rangka Meningkatkan Pendidikan Masyarakat (Bambang Hemanto), (9) Optimalisasi Layanan Perpustakaan Perguruan Tinggi melalui Pemanfaatan Social Media Networking sebagai Media Komunikasi antara Perpustakaan dan Pemustaka (Haryanto).

Akhirnya, redaksi JPI mengucapkan banyak terima kasih kepada Kepala UPT Perpustakaan UNS yang telah memberikan dukungan dan memfasilitasi untuk penerbitan JPI. Selain itu, ucapan terima kasih juga disampaikan kepada para penulis, tim redaksi, dan Yuma Pressindo, yang telah mempersiapkan dari awal sampai terbitnya JPI.

Desember 2015

Ketua Redaksi, 


\section{SAMBUTAN}

Dr. Muhammad Rohmadi, M.Hum.

Kepala UPT Perpustakaan UNS

\section{“Jadikalah tulisanmu sebagai cermin kehidupanmu di masa sekarang dan masa depan"}

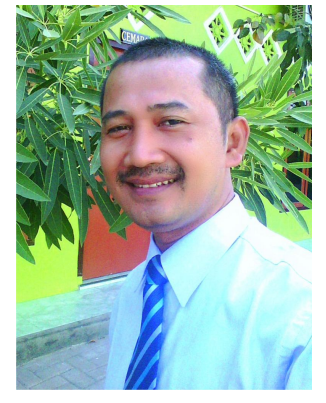

Selamat dan sukses atas diterbitkannya Jurnal Pustaka Ilmiah (selanjutnya disingkat JPI). Sambutan ini diberikan dalam rangka penerbitan perdana JPI. Jurnal ini sebagai media kreativitas dan pengembangan softskill para pustakawan, guru, dosen, dan praktisi untuk menuangkan ide dan gagasan dalam berbagai konteks kehidupan. Berbagai isu terkait dengan pengembangan perpustakan, pusat sumber belajar, pendidikan, dan budaya literasi akan menjadi topik-topik yang disajikan dalama jurnal ilmiah ini.

Diterbitkannya JPI sebagai bukti kepedulian UPT perpustakaan Ilmiah dalam rangka turut berpartisipasi untuk mengembangkan dan membudayakan literasi untuk para pustakawan dan civitas akademika di UNS dan luar UNS. Berbagai model pengembangan softskill menjadi alaternatif untuk membekali dan memperkuat jaringan kerja sama penulisan antarkelembagaan. Dengan demikian, kerja sama antarpustakawan dan pemustaka dapat diwujudkan dengan berbagai model dalam bidang literasi.

Penerbitan JPI sebagai upaya untuk memotivasi semua pustakawan menulis, baik ilmiah maupun nonilmiah. Para pustakawan harus menjadi pionir dalam bidang penulisan. Hal ini sebagai bentuk kepedulian dan keteladaan para pustakawan yang memproses, menyajikan, dan menikmati bahanbahan pustaka cetak dan noncetak di perpustakaan. Ketersedian bahan pustaka akan menjadi bahan paling nyata untuk dikembangkan dalam berbagai model perwujudan teknik peniulisan. Hal terpenting yang harus dimiliki oleh para pustakawan adalah semangat untuk berbagai pengetahuan melalui tulisan.

Kepedulian setiap sumber daya manusia kepada kelembagaan dapat dituangkan dalam berbagai model pengabdian, salah satunya adalah melalui tulisan. Berbagai ide dan gagasan dapat direalisasikan dengan berbagai model bentuk artikel jurnal, buku, modul, monograf, dan lain sebagainya. Para civitas akademika, guru, praktisi harus memiliki keterampilan menulis sebagai bentuk perwujudan pengembangan diri secara berkelanjutan. Berbagai tulisan dan referensi sudah disajikan tetapi masih sangat minim untuk diimplementasikan dalam kehidupan. Banyak orang pandai dalam berbicara tetapi masih sedikit yang menuangkan ide dan gagasannya dalam bentuk tulisan.

Akhirnya, keluarga besarUPT Perpustakaan UNS mengucapkan banyak terima kasih kepada Rektor, Wakil Rektor, pengelola JPI, penulis, dan semua pihak yang telah mendukung penerbitan perdana JPI. Semoga dengan diterbitkannya JPI ini dapat menjadi media untuk menulis para pustakawan, dosen, guru, dan praktisi dalam bidang iptek dan seni. Ucapan terima kasih juga diucapkan kepada percetakan Yuma Pressindo yang telah membantu mempersiapkan dari awal sampai terbitnya JPI ini. Akhirnya, semoga JPI dapat memberikan nilai kemaslahatan untuk umat.

“Berdiri kemudian berbaring sangatlah cepat tetapi tatkala sudah dituliskan akan menjadi kenangan yang taidak terlupakan sepanjang hayat”

Surakarta, Desember 2015 


\section{DAFTAR ISI \\ JURNAL PUSTAKA ILMIAH EDISI 1 VOLUME 1 TAHUN 2015}

Simbiosis Mutualisme Perpustakaan dengan Media Cetak sebagai Upaya Membudayakan Membaca dan Menulis bagi Masyrakat

Muhammad Rohmadi

Faktor Pengembangan dan Isu dalam Masalah Karier Pustakawan.

Masriyatun

Menguak Informasi via Alexa.com sebagai Evaluasi Menuju Optimalisasi Keberaksesan terhadap Perpustakaan dan Institusinya

Wiji Suwarno

Profesionalisme Pustakawan dalam Layanan Informasi

Sri Anawati

Public Space dan Private Space: Posisi Strategis Perpustakaan dalam Mendukung Pembelajaran Kolaboratif

Purwani Istiana

Mewujudkan World-class Professionalism of Librarians di Era Library Mobile

Yuni Nurjanah

Tantangan dan Kesiapan Pustakawan di Era Digital

Dian Hapsari

Formulasi Strategi Membangun Eksistensi Perpustakaan Perguruan Tinggi (Studi UPT Perpustakaan UNS Tahun 2015)

Riah Wiratningsih

Optimalisasi Perpustakaan Desa dalam Rangka Meningkatkan Pendidikan Masyarakat Bambang Hemanto

Optimalisasi Layanan Perpustakaan Perguruan Tinggi melalui Pemanfaatan Social Media Networking sebagai Media Komunikasi antara Perpustakaan dan Pemustaka Haryanto 


\title{
MENGUAK INFORMASI VIA ALEXA.COM SEBAGAI EVALUASI \\ MENUJU OPTIMALISASI KEBERAKSESAN TERHADAP \\ PERPUSTAKAAN DAN INSTITUSINYA
}

\section{Wiji Suwarno}

\begin{abstract}
Website institutions is an important part in order to promoting an institution to public widely. Website able to penetrate the various layers of society in a variety of conditions. Therefore, alexa.com initiative to calculate and make coarse count data of various possibilities for the treatment of society against the institution's website, so that it can be made a ranking, a good popularity world-class website and the state level, people's interest in the website, and also parts which websites most interested in a particular website's home institution.
\end{abstract}

Keywords: institutional website, evaluation, optimization of access

\begin{abstract}
ABSTRAK
Website institusi merupakan bagian penting dalam rangka memperkenalkan institusi kepada masyarakat secara luas. Website mampu menembus berbagai lapisan masyarakat dalam berbagai kondisi. Karenanya, alexa.com berinisiatif untuk menghitung dan membuat data hitungan kasar berbagai kemungkinan perlakuan masyarakat terhadap website institusi tersebut, sehingga bisa dibuat suatu peringkat, baik kepopuleran website tingkat dunia maupun tingkat negara, ketertarikan masyarakat terhadap website, dan juga bagian-bagian website mana yang paling diminati dalam rumah website institusi tertentu.
\end{abstract}

Kata kunci: website institusi, evaluasi, optimalisasi akses

\section{PENDAHULUAN}

Sempatkah kita perhatikan ketika sedang bersantai menikmati keindahan kehidupan di sebuah kota? Ada kejadian menarik ketika di pinggir jalan yang penuh dengan kesibukan orang berlalu-lalang. Suatu ketika nampak seseorang (sebut saja A) sedang kebingungan sambil memegang secarik kertas, lalu ia menghampiri seseorang lainnya (sebut saja B) yang sedang duduk di tepi trotoar di samping tanaman bunga. Selidik boleh selidik, si A menanyakan tentang alamat kantor tertentu kepada si B, yang diharapkan paham daerah di sekitar wilayah yang dimaksud. Benar saja, tidak berapa lama si $\mathrm{B}$ menunjukkan dengan bahasa lisan didukung dengan isyarat menunjukkan arah, si A pun bergegas pergi dan mengikuti arahan si B tadi.

Ilustrasi ini mengajak pembaca pada arti pentingnya informasi. Informasi merupakan istilah yang sudah tidak asing lagi didengar. Pada dasarnya informasi merupakan suatu data, baik data numerik maupun verbal yang telah diolah sedemikian rupa sehingga mempunyai arti. Zorkoczy (1999: 7) mendefinisikan informasi sebagai pengetahuan yang disampaikan kepada orang lain berdasarkan suatu fakta. Informasi juga dikatakan sebagai data yang telah diproses ke dalam suatu bentuk, yang mempunyai arti bagi si penerima dan mempunyai nilai 
nyata, serta terasa bagi keputusan saat itu dan keputusan mendatang (Sutabri, 2005: 15).

Ada nilai penting informasi sebagai orientasi pada sebuah kepastian menentukan keputusan. Begitu pentingnya informasi sebagaimana ilustrasi di depan sehingga seseorang akan kesulitan mencapai tujuannya tanpa informasi yang cukup mengenai hal yang dituju. Anggaplah kita ingin pergi ke Paris. Keinginan itu cukup kuat mendorong dari dalam diri sampai mendekati keharusan untuk dilakukan. Akan tetapi, informasi mengenai persyaratan, birokrasi, bahkan detail transportasi dan medan di sana tidak lengkap, maka dapat dibayangkan apa yang terjadi. Tentu berbagai kesulitan akan dihadapi, bahkan berakibat tidak terwujudnya keinginan itu.

\section{Hakikat Informasi}

Informasi bukan lagi istilah yang langka didengar oleh masyarakat. Kata informasi bukan lagi konsumsi pakar informasi saja, tetapi informasi yang sudah menjelajah ke alam pikir dan ungkapan verbal orang-orang yang asyik bercakap di warung makan kaki lima hingga perkantoran.

Pada hakikatnya informasi itu berawal dari adanya data, kemudian data itu dioleh sedemikian rupa sehingga menjadi sebuah pengertian dan pemahaman bagi penerimanya. Data itu sendiri bisa mengenai data mentah, data tersusun, kapasitas sebuah saluran komunikasi, dan sebagainya. Jika diarahkan pada sebuah organisasi, maka informasi ibarat darah yang mengalir di dalam tubuh suatu organisasi sehingga informasi ini menjadi sangat penting. Suatu organisasi yang kurang mendapatkan informasi akan menjadi luruh, kerdil, dan akhirnya mati. "Information is data that has been processed into a form that is meaningful to the reciepient and is of real or perceived value in current or prospective actions or decisions".

Di lain pihak, dikatakan bahwa informasi adalah sekumpulan data yang dikomunikasikan dalam bentuk yang dapat dipahami. Informasi merupakan konten dari berbagai format, misalnya informasi yang tertulis atau tercetak, tersimpan dalam database, atau terkumpul dalam suatu internet. Informasi juga dapat berupa pengetahuan staf dalam suatu organisasi (perekayasaan informasi, manajemen informasi, dan ilmu informasi). Istilah informasi mencakup berbagai aktivitas yang saling berkaitan menggunakan istilah kepustakawanan.

Sementara itu, dalam pandangan Saracevic (dikutip oleh Pendit, 2007: 13), informasi dikelompokkan dalam tiga pengertian. 1) Secara sempit adalah sebagai serangkaian sinyal atau pesan-pesan yang diperlukan dalam pengambilan keputusan; 2) informasi dalam arti luas yang dikaitkan dengan proses kognitif dan kemampuan memahami pada diri manusia; 3) lebih luas, informasi tidak hanya dikaitkan dengan pesan atau proses semata, tetapi juga dengan konteks sosialnya, berupa situasi, persoalan, kajian tugas, dan sebagainya. Informasi dapat juga diartikan sebagai pengetahuan yang menjadi milik bersama karena dikomunikasikan dalam bentuk rekaman. Selain itu, informasi yang dikelola oleh perpustakaan bersifat publik atau sosial karena dapat dimanfaatkan secara bebas oleh semua anggota masyarakat.

Informasi sangat bernilai bagi yang menggunakannya. Namun demikian, suatu informasi mempunyai arti atau nilai tergantung pada pemakainya. Informasi yang tepat sasaran akan sangat berarti dan bernilai tinggi. Sebaliknya, informasi yang salah sasaran tidak ada artinya sama sekali. Oleh karena itu, nilai suatu informasi tergantung pada siapa penerimanya. Informasi yang baik adalah informasi yang memiliki makna atau dengan kata lain sesuai dengan kebutuhan penerima. Informasi memiliki nilai-nilai sebagai berikut.

1. Benar dan salah, informasi selalu berhubungan dengan kebenaran dari suatu kenyataan. Jika informasi salah tetap 
dipercayai, maka dampaknya sama dengan jika informasi itu benar.

2. Baru, informasi adalah baru bagi penerimanya.

3. Tambahan, informasi bisa berupa perbaruan atau perubahan dari informasi sebelumnya.

4. Korektif, informasi bisa untuk melakukan koreksi terhadap informasi sebelumnya yang salah.

5. Penegas, dapat memberikan penegasan bagi informasi sebelumnya sehingga meningkatkan keyakinan penerima.

Informasi sebagai Sumber Daya dan Aset Perpustakaan

Pembangunan perekonomian dalam menghadapi persaingan global, diperlukan andil dari semua unsur untuk terlibat secara proaktif dan antisipatif. Dalam pasal 1 Undang-Undang perpustakaan nomor 43 tahun 2007, disebutkan bahwa perpustakaan adalah institusi pengelola koleksi karya tulis, karya cetak, dan/atau karya rekam secara profesional dengan sistem yang baku guna memenuhi kebutuhan pendidikan, penelitian, pelestarian, informasi, dan rekreasi para pemustaka"

Perkembangan zaman saat ini ditandai dengan terjadinya perubahan yang sangat cepat dalam segala bidang kehidupan masyarakat. Perpustakaan sebagai lembagayang orientasinya melayani masyarakat penggunannya harus tanggap dengan perubahan itu kalau tidak ingin di tinggalkan. Perpustakaan harus cepat beradaptasi dengan perkembangan yang terjadi, tidak mengisolisasi dalam dunianya sendiri. Perpustakaan tidak perlu mengubah fungsi utama yang kini dijalaninya, tetapi harus menyesuaikan dengan perkembangan zaman. Untuk itu, perpustakaan harus bekerja keras meningkatkan efisiensi dalam menjalankan fungsi sebagai pengelola informasi.

Setiap perpustakaan memiliki tanggung jawab dengan tuntutan profesionalisme pengelolaan guna menjawab perkembangan zaman dan merespon serta berusaha memenuhi kebutuhan pemakai yang selalu berkembang. Semua itu tidak sederhana dan tak pernah berakhir, tetapi akan terus berubah, berinovasi, dan menyesuaikan dengan lingkungan kehidupan masyarakat.

Di negara-negara yang sudah maju, perpustakaan merupakan cermin kemajuan masyarakatnya. Hal itu menunjukkan bahwa perpustakaan adalah bagian dari kebutuhan hidup sehari-hari. Sementara di negara-negara berkembang, keberdaaan, eksistensi, dan perhatian masyarakat terhadap perpustakaan masih sangat terbatas. Penyebabnya beraneka ragam, di antaranya orang lebih atau masih mementingkan pemenuhan kebutuhan sosial ekonomi sebelum menjadikan perpustakaan sebagai prioritas kebutuhannya. Perpustakaan masih merupakan keinginan (wants) daripada kebutuhan (needs) bagi sebagian orang. Artinya bahwa kesadaran dan pemahaman tentang perlunya layanan perpustakaan sebagai sumber informasi dan ilmu pengetahuan sudah ada, mulai menggejala dan berkembang, tetapi belum merupakan prioritas utama. Di sisi yang lain, untuk menyediakan perpustakaan yang representatif, merata, dan mampu menjangkau seluruh lapisan masyarakat, masih menghadapi tantangan yang tidak sederhana.

Sutarno (2005: 13) mengemukakan ada beberapafaktoryangmenyebabkan perpustakaan belum dapat berkembang dan masih belum bisa berdiri sendiri, di antaranya adalah pengelola perpustakaan, sumber informasi, dan masyarakat pemakai. Perpustakaan belum mampu menyediakan sumber informasi yang berkembang dan dibutuhkan oleh pemakai dan melayani masyarakat pemakai dengan lebih profesional, kemudian belum mampu bersaing dengan lembaga-lembaga yang bergerak dalam bidang jasa imformasi lainnya, seperti pusat penelitian, lembaga demografi, dan pusat data bisnis. Pengelola perpustakaan harus dapat menempatkan posisinya secara tepat, kemudian menjawab pertanyaan-pertanyaan mengenai 
status organisasi, sumber daya manusia, sumber informasi, sumber fisik, dan sumber anggaran, serta promosi dan publikasi yang memadai. Jika semua itu terpenuhi dengan baik, maka separuh persoalan telah terjawab.

Faktor yang kedua, yaitu mengenai kemampuan memilih, menghimpun/ mengadakan, dan menyajikan informasi kapada pemakai sangat tergantung kepada kemampuan memilih, memilah, menghimpun/mengadakan, dan menyajikan apa yang dibutuhkan oleh masyarakat. Persoalan yang ketiga adalah dalam hal mengembangkan citra yang baik dan bagaimana membangun persepsi, respons, minat, dan memotivasi pemakainya.

Tersedianya berbagai sumber informasi dan dengan kecanggihan teknologi informasi komunikasi, memudahkan pengguna untuk dapat langsung mengakses informasi tanpa bantuan perpustakaan. Akhirnya, timbul pertanyaan apalagi yang harus dilakukan oleh perpustakaan?

Menurut Suwarno (2010: 15), untuk menjawab pertanyaan ini adalah dengan merumuskan peran perpustakaan di abad 21 sebagai berikut.

1. Memberikan fasilitas akses terhadap sumber elektronik bagi mereka yang tidak memiliki akses itu secara fisik, termasuk reproduksinya. Ketidakmampuan seseorang untuk membeli semua sumber informasi yang dibutuhkan membuatnya menggunakan jasa perpustakaan yang relatif murah.

2. Membimbing pengguna mencari dan memiliki sumber informasi yang sesuai dengan kebutuhannya berdasarkan kemampuan profesionalisme yang dimiliki staf perpustakaan. Asumsi yang dipakai adalah tidak semua pencari infromasi adalah pengguna dan tidak semua pengguna dapat memenuhi kebutuhan infromasinya sendiri, terutama bila subjek itu di luar bidang yang dikuasainya.
3. Mengkoleksi, mengatalog, dan mengindeks bahan pustaka. Keterampilan mengorganisasi informasi ini akan memberikan kemudahan untuk mengaksesnya, baik informasi dalam bentuk cetak maupun versi elektronik.

Singkatnya, era keberaksesan "dunia maya" ini menuntut kreativitas dan progresivitas perpustakaan agar pemustaka menjelajah dalam alam maya perpustakaan. Ini berarti aset perpustakaan perlu dioptimalkan. Penyertaan koleksi digital yang mendampingi koleksi konvensional menjadi tuntutan yang harus dijawab perpustakaan.

Melalui sebuah sistem maya (sebut saja alexa.com), kita bisa menilai dan mengevaluasi tingkat keberaksesan pemustaka terhadap "rumah" perpustakaan suatu lembaga/institusi.

\section{Uji Keberaksesan Informasi dengan alexa. com}

Perpustakaan sebagai lembaga pengelola informasi yang mendukung cita-cita lembaga induknya memiliki peranan penting dalam diseminasi informasi. Hal ini tentu terkait dengan kemudahan akses terhadap informasi yang dimiliki. Perlu disampaikan bahwa kemudahan akses menjadi salah satu indikator baik atau tidaknya suatu website untuk eksis. Alat ukur keberaksesan cukup beragam dan memiliki kualifikasi masing-masing. Dari alat ukur ini, setidaknya akan diketahui kuantitas dan kualitas informasi yang ada. Salah satu perangkat yang bisa digunakan untuk mengukur tingkat keberaksesan terhadap informasi lembaga adalah dengan bantuan web alexa.com .

Tentu muncul pertanyaan, apakah alexa. com itu? Alexa.com merupakan anak perusahaan dari amazon.com. Dari sana, kita difasilitasi untuk mendapatkan gambaran singkat tentang "rumah" institusi kita dari masing-masing maupun institusi lain yang kita ketahui alamat websitenya, baik itu tentang peringkat atau rangking global dan peringkat di negara asal situs. Setidaknya, beberapa informasi penting 
yang ada pada alexa yang perlu diperhatikan, antara lain: global rank, rank in Indonesia, bounce rate, daily pageviews per visitor, daily time on site, dan total sites linking in.

\section{Popularitas Website Institusi}

Institusi tempat perpustakaan bernaung memiliki peranan penting bagi kemajuan perpustakaan, tidak terkecuali pada tingkat kepopulerannya. Asumsinya, jika institusi dikenal masyarakat secara luas, maka setidaknya perpustakaan yang merupakan bagian dari institusi itu memungkinkan untuk dikenal pula oleh masyarakat. Era internet menstimulasi masyarakat beraktivitas menggunakan jasa

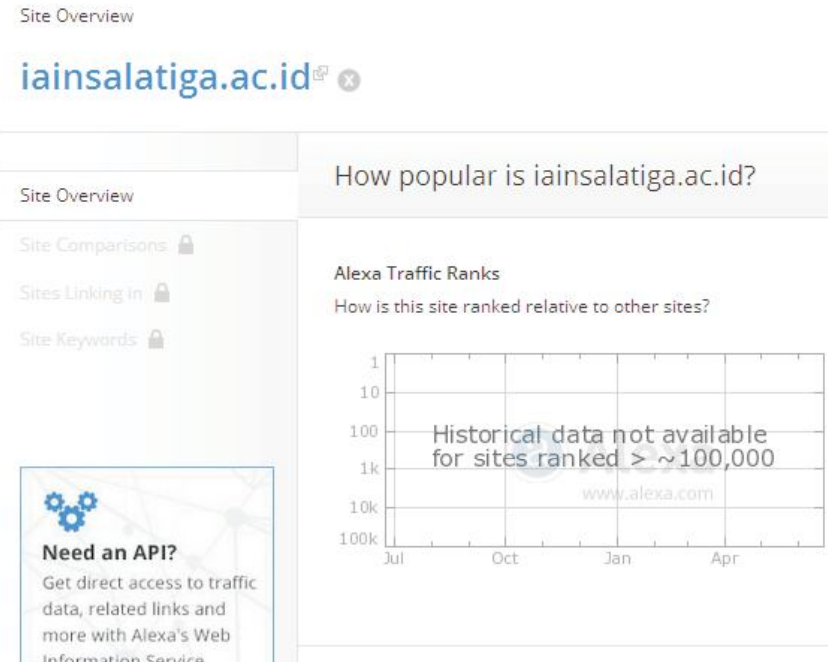

internet, tidak terkecuali ketika masyarakat membutuhkan informasi cepat, tanpa perlu beranjak dari rumah mereka masing-masing, tetapi mampu mengakses informasi yang selengkap-lengkapnya, dan tidak ada cara lain kecuali berselancar di dunia maya dengan berbekal alamat-alamat situs yang memuat informasi yang mereka butuhkan. Dengan demikian, dari aktivitas mereka ini dapat dilihat sejauh mana kepopuleran suatu insitusi dari sudut pandang tingkat akses mereka.

Sebagai contoh, ditampilkan di sini situs IAIN Salatiga, sebagaimana penulis bernaung pada institusi tersebut. Pada gambar berikut ini diinformasikan sebagai berikut.

Gambar 1. Informasi Global Rank dan Rank in Indonesia

Gambar di atas menunjukkan seberapa populer situs IAIN Salatiga. Sebagaimana dikemukakan oleh Webb \& Powis (2004: 9), pada dasarnya kemampuan memberikan kemudahan mengakses informasi menjadi bagian dari kebijaksanaan dunia penyedia informasi. Ini menjadi salah satu strategi dalam meningkatkan popularitas website. Berdasarkan gambar di atas, diperoleh informasi bahwa ada dua hal yang bisa diamati dari tampilan tersebut, yaitu global rank dan rank in Indonesia.

\section{Global Rank}

Informasi ini memberikan penjelasan tentang perkiraan kasar dari popularitas situs tertentu (dalam hal ini IAIN Salatiga) dibandingkan dengan situs-situs lain di internet seluruh dunia. Peringkat tertinggi adalah \#1 (nomor rendah adalah peringkat yang lebih tinggi). Google.com saat ini menduduki peringkat \#1, dan peringkat paling rendah adalah \#2.900.000. Artinya, jika peringkat situs tertentu lebih dari 2,9 juta, maka situs itu tidak masuk dalam hitungan peringkat dunia. Sebagaimana gambar di atas, IAIN Salatiga menduduki peringkat 187.666 di antara situs lain di dunia.

\section{Rank in Indonesia}

Informasi ini lebih mengerucut pada peringkat popularitas situs di negara tertentu (contoh: Indonesia). IAIN Salatiga yang 
berada dalam wilayah negara Indonesia, jika dibandingkan situs populer lainnya di Indonesia, berdasarkan data pada gambar di atas, menduduki peringkat 3.024. Ini merupakan sebuah perkiraan kasar sebagaimana penghitungan pada global rank. Pendek kata, semakin kecil angka yang ditampilkan pada rank in Indonesia, maka semakin populer situs tersebut di Indonesia.

Untuk tingkat kepopuleran ini sesungguhnya bisa pula dilihat pada webometric.com, di mana suatu perguruan tinggi menempati posisi tertentu berdasarkan ranking, baik secara nasional, teritorial, maupun internasional.

\begin{tabular}{|c|c|c|c|c|c|c|c|}
\hline ranking & $\begin{array}{l}\text { World } \\
\text { Rank }\end{array}$ & University & Det. & $\begin{array}{l}\text { Presence } \\
\underline{\text { Rank }^{*}}\end{array}$ & $\underline{\text { Impact }}$ & $\begin{array}{l}\text { Openness } \\
\text { Rank: }\end{array}$ & $\begin{array}{l}\text { Excellence } \\
\text { Rank* }\end{array}$ \\
\hline 168 & 13086 & Universitas Maritim Raia Ali Haii & EDI & 9947 & 14898 & 5922 & 5490 \\
\hline 169 & 13144 & Malanqkucecwara School of Economics & $E$ & 7564 & 13288 & 15808 & 5490 \\
\hline 170 & 13187 & Universitas Islam Riau & 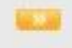 & 8369 & 15681 & 4916 & 5490 \\
\hline 171 & 13240 & Politeknik Negeri Malang & Ex] & 6700 & 15570 & 7309 & 5490 \\
\hline 172 & 13423 & Universitas Pakuan & $E=$ & 9454 & 13626 & 14158 & 5490 \\
\hline 173 & 13522 & Universitas Borneo & $\sqrt{200}$ & 7470 & 13638 & 16376 & 5490 \\
\hline 174 & 13609 & Universitas Muhammadivah Ponorogo & EDI & 8391 & 14435 & 13141 & 5490 \\
\hline 175 & 13619 & $\begin{array}{l}\text { National Institute of Technologr Malang I } \\
\text { Institut Teknologi Nasional Malang }\end{array}$ & E. & 11205 & 14386 & 10518 & 5490 \\
\hline 176 & 13652 & Institut Agama Islam Negeri IAIN Salatiga & wivin & 5496 & 17515 & 2425 & 5490 \\
\hline 177 & 13665 & Universitas Semarang & 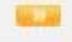 & 9375 & 14554 & 11975 & 5490 \\
\hline 178 & 13752 & PPM School of Management & 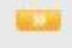 & 14446 & 13831 & 10947 & 5490 \\
\hline 179 & 13757 & Universitas Mahasaraswati Denpasar & Eve & 12506 & 13962 & 12188 & 5490 \\
\hline 180 & 13830 & President University & 필 & 15078 & 13359 & 13141 & 5490 \\
\hline 181 & 13888 & Universitas Bunda Mulia & $\sqrt{E D}$ & 9102 & 14537 & 13656 & 5490 \\
\hline 182 & 13960 & University Dr Soetomo Surabava & 필 & 13041 & 14514 & 10638 & 5490 \\
\hline 183 & 13960 & $\begin{array}{l}\text { Sekolah Tinqqi Manajemen Informatika } \\
\text { dan Teknik Komputer Bali }\end{array}$ & EDin & 7667 & 14588 & 15276 & 5490 \\
\hline 184 & 14013 & STIE YKPN Yoqvakarta & 릴 & 9088 & 15198 & 11485 & 5490 \\
\hline 185 & 14031 & Universitas Palanqka Rava & 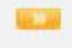 & 16647 & 12960 & 19804 & 4898 \\
\hline 186 & 14086 & $\begin{array}{l}\text { STT Telematika Telkom Purwokerto } \\
\text { (Akademi Teknik TELKOM) }\end{array}$ & $\sqrt{2}$ & 9344 & 14439 & 14956 & 5490 \\
\hline 187 & 14086 & $\begin{array}{l}\text { Sekolah Tinqgi Manaiemen Risiko Dan } \\
\text { Asuransi }\end{array}$ & 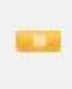 & 14730 & 11484 & 19563 & 5490 \\
\hline
\end{tabular}

Namun demikian, google tersebut hanya membuat ranking daftar nama perguruan tinggi yang dapat diurutkan melalui visiblitas dan keberaksesan terhadap portal tersebut.

\section{Tingkat Ketertarikan Konsumen}

Pepatah lama mengatakan bahwa konsumen adalah raja. Sedikit banyak pepatah ini mengandung kebenaran bahwa konsumen perlu dimanjakan, dilayani, dan dihargai. Ini semata menjadi strategi dagang agar komoditi

menjadi berkualitas sehingga lebih diminati. Sama halnya dengan website, semakin menarik tampilan, isi, maupun kemudahan pemahaman terhadap informasi yang disajikan, semakin menjadi kekuatan bagi website untuk digemari konsumennya. Maka, alexa.com membaca kecenderungan itu dengan memberikan statistik bounce rate.

\section{Bounce rate}

Bounce rate adalah perhitungan jumlah persen orang yang mengunjungi website 
tertentu, tetapi ia meninggalkan situs itu setelah melihat hanya pada satu halaman saja. Analisisnya, pada umumnya tingkat bouncing semakin rendah. Artinya, angka bounce semakin sedikit, maka situs semakin baik. Menurut inc.com, tingkat bouncing lebih tinggi dari $80 \%$ bisa dikatakan buruk, sementara $50 \%$ bisa disebut biasa saja alias tidak istimewa, ada pun di bawah 30\% artinya sangat baik. Lebih kecil persennya berarti konten situs Anda bisa disebut menarik. Lihat pada gambar 2 berikut ini.

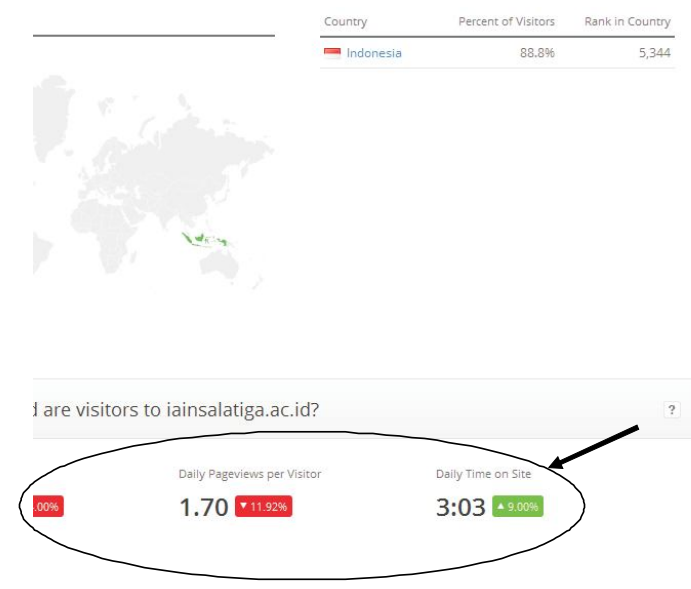

Gambar 2. Informasi Daya Tarik Website terhadap Pengunjung

Penganalisaan terhadap daya tarik pengunjung ini, biasanya dilakukan oleh program-program layanan, baik dari organisasi, lembaga swasta, maupun lembaga negeri yang dijaringkan menggunakan model LAN. Namun demikian, program-program ini belum bisa melihat secara utuh per halaman atau bagian yang dikunjungi pengguna. Sedangkan alexa. com, sudah dapat melakukannya.

\section{Daily Pageviews per Visitor}

Masyarakat penggunayang melakukanakses terhadap website sangat bergantung pada minat mereka terhadap informasi di dalamnya. Maka, sangat dimungkinkan perlakuan konsumen terhadap suatu website berbeda terhadap website lainnya. Maka, alexa.com menghitung ratarata jumlah halaman yang dilihat oleh setiap pengunjung saat masuk ke situs web tertentu/ per hari. Jika jumlah angkanya menunjukkan lebih tinggi, berarti situs itu dianggap memiliki informasi yang lebih menarik dan begitu juga sebaliknya, jika nilainya rendah, artinya pengunjung tidak mengklik halaman pada website itu, melainkan berlalu pergi tanpa ada aktivitas terhadap website. Jika angka pada gambar di atas menunjukkan 1.70 dan $11.92 \%$, maka website IAIN Salatiga dilihat oleh visitor sejumlah 1.70 halaman per hari atau sekitar $11.92 \%$ dari seluruh halaman yang dimiliki website IAIN Salatiga.

\section{Daily Time on Site}

Visitor selalu memerlukan waktu untuk melihat tampilan, memahami substansi website atau bahkan menelusur ke halamanhalaman detail website. Alexa.com mendeteksi jumlah waktu yang diperlukan visitor ketika mengunjungi website tersebut. Maka, daily time on site ini mengajak pembaca memahami tentang jumlah rata-rata menit yang dihabiskan visitor untuk berselancar di situs web tertentu. Hal yang perlu diketahui adalah bahwa ketika angka ini lebih tinggi, maka situs itu dianggap memiliki informasi yang lebih menarik. Artinya, pengunjung betah berlama-lama berselancar di situs itu. Jika melihat pada data yang ditunjukkan oleh alexa.com sebagaimana gambar di atas adalah 3.03 dan 9\%, maka dapat dibaca bahwa rata-rata waktu yang diperlukan untuk melihat website IAIN Salatiga adalah 3.03 jam atau sekitar 9\% dari waku 24 jam yang tersedia dalam satu hari.

Terdapat fenomena sebagai catatan, bahwa sebagai bounce rate, ada satu pengecualian apabila informasi pada setiap halaman web begitu tepat sasaran yang menyediakan semua informasi yang dibutuhkan pengunjung. Hal ini dapat menyebabkan tingkat bouncing yang tinggi karena mereka meninggalkan situs dengan rasa puas setelah melihat (walaupun) hanya satu halaman. Contoh: The New York Times memiliki tingkat bouncing dari $62 \%$, tetapi peringkat 111 di dunia. Tingkat bouncing yang tinggi tidak selalu berarti buruk. Sebagai 
catatan, perlu kiranya kita memperhatikan kotak hijau atau merah yang muncul di sebelah setiap statistik. Hal ini menunjukkan persentase perubahan selama 3 bulan terakhir. Jika persentase ditampilkan dalam kotak hijau, itu berarti statistik situs membaik. Jika persentase ditampilkan dalam kotak merah, itu berarti statistik telah memburuk.

\section{Popularitas Website Dilihat Link dari Website Lain}

Ibarat hubungan interpersonal, jika seseorang memiliki karakter baik, gaya hidup yang baik, dan menjadi inspirasi positif bagi individu lainnya, maka kecenderungannya adalah ia akan memiliki banyak teman, bahkan orang lain pun mengaku saudara. Tidak ubahnya website yang baik, dia akan mendapatkan respons positif dari visitor dan bahkan mereka akan dengan sukarela menghubungkan (membuat link) website mereka dengan website yang dianggap mereka itu baik. Maka, alexa. com berupaya mendeteksi link-link yang terjalin antarsatu website dengan website lainnya.

\section{Total Sites Linking In}

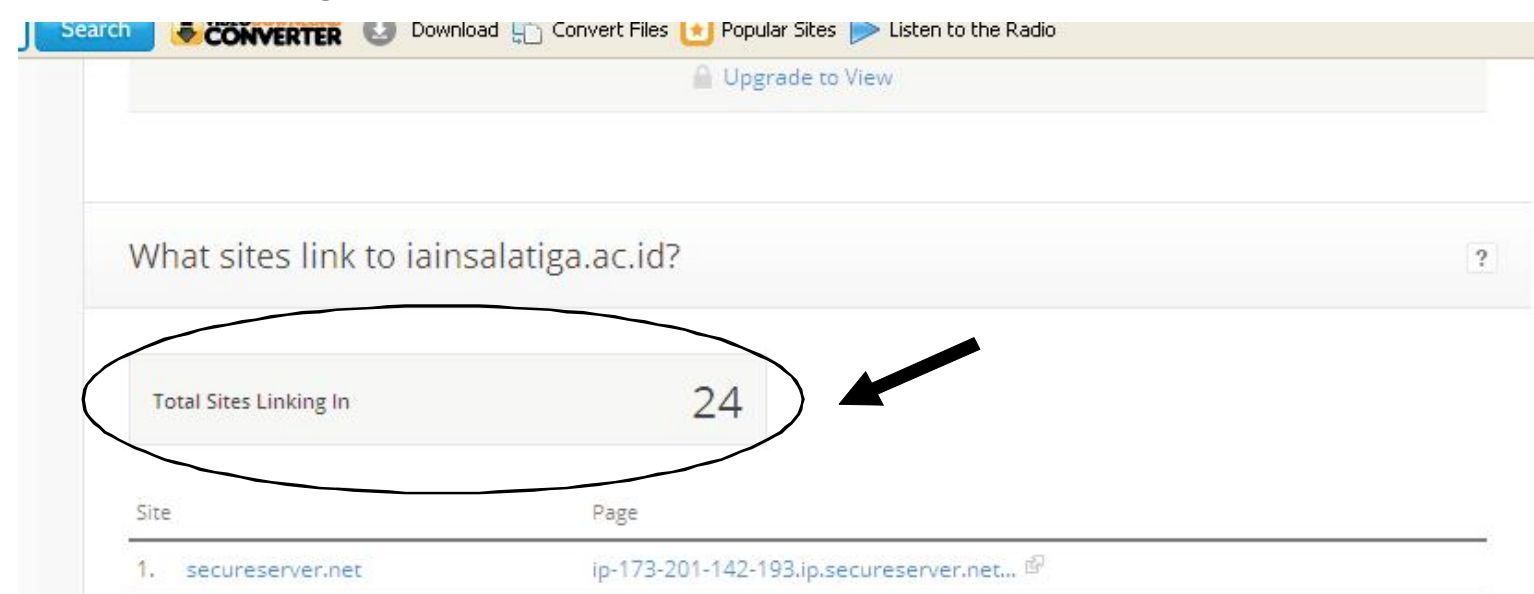

Gambar 3. Informasi Link ke Website IAIN Salatiga

Data pada gambar di atas menunjukkan jumlah situs yang memiliki link ke website tertentu, dalam hal ini websitenya IAIN Salatiga. Link dari website lain ini diperlukan sebagai dasar untuk membantu domain mengembangkan "otoritas", semakin banyak link in menggambarkan kualitas situs website tertentu. Oleh karena itu, sangat penting untuk membangun hubungan yang relevan dengan situs lainnya. Data di atas menunjukkan bahwa ada 24 link yang merujuk pada website IAIN Salatiga. Perolehan angka ini dapat menjadi bahan analisis bahwa website IAIN Salatiga sudah dikenal oleh minimal 24 perguruan tinggi yang membuat link dengan website IAIN Salatiga.

\section{Kecenderungan Aktivitas Visitor pada Website}

Website merupakan "rumah maya" dari institusi yang memiliki berbagai kamar. Ada halaman utama sebagai muka dari halaman website, ada pula ruangan-ruangan penting dari berbagai unit yang merupakan pendukung kelengkapan isi dari rumah website tersebut. Kenyamanan, kelengkapan informasi, dan kebutuhan terhadap informasi di dalamnya tentu menjadi pilihan visitor untuk surfing di ruangan-ruangan itu. Perhatikan gambar berikut ini. 


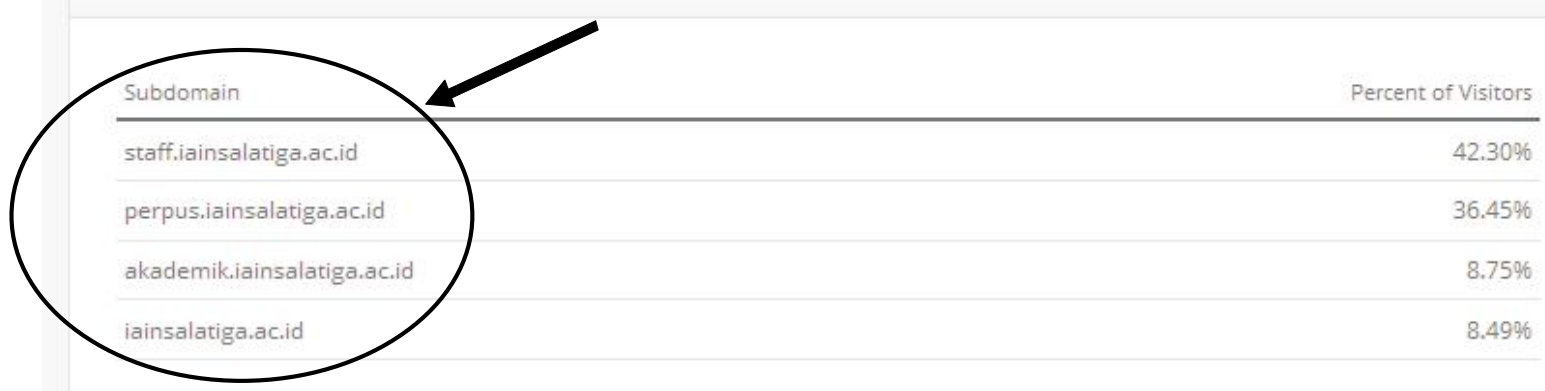

Gambar 4. Informasi Kecenderungan Kunjungan pada Halaman Tertentu pada Website

Pada gambar di atas terdapat empat pemustaka berdiam dan menggeluti informasi ruangan favorit yang dikunjungi oleh visitor, di dalamnya. Era digitalisasi, era e-book, ada ruangan staff, perpustakaan, akademik, e-journal atau jenis koleksi elektronik lainnya dan rumah induknya. Alexa.com menelisik justru menjadi peluang bagi perpustakaan untuk kebutuhan visitor ini dari berbagai website mendekati pemustakanya, tetapi juga menjadi di seluruh dunia. Salah satunya adalah rumah IAIN Salatiga, di mana ruangan paling sering dikunjungi adalah ruangan staff dengan nilai $42.30 \%$, diikuti ruangan perpustakaan dengan angka $36.45 \%$, kemudian ruangan akademik $8.75 \%$, dan urutan keempat adalah ruangan induk IAIN Salatiga dengan presentasi $8.49 \%$.

Data tersebut sebenarya dapat menjadi bahan evaluasi bagi institusi untuk menentukan keputusan lebih lanjut tentang perbaikanperbaikan strategi agar visitor menjadi lebih nyaman berkunjung dan mengakses informasi dari website-nya. Terkait dengan popularitas kunjungan per unit pada lembaga melalui portal, portal lain hanya sebatas menunjukkan intensitas kunjungan secara global, tanpa ada analisis terhadap kunjungan pada masingmasing unit.

\section{Bagaimana Peran Perpustakaan?}

Optimalisasi sumber daya yang dimiliki perpustakaan memungkinkan perpustakaan menjadi ruang pilihan pada rumah institusi yang akan sering dikunjungi. Perpustakaan memiliki kans yang besar untuk menjadi pilihan tantangan yang menarik ketika perpustakaan belum memiliki sumber daya ini.

\section{PENUTUP}

Berdasarkan pemaparan di atas, dapat diambil kesimpulan sebagai berikut. Pertama, website merupakan "rumah" institusi yang ditampilkan secara online yang perlu diperindah dan diisi content yang bermanfaat bagi visitor. Kedua, keberaksesan terhadap website oleh visitor dapat dipantau (salah satunya) menggunakan alexa.com yang mendata tentang aktivitas visitor pada website terkait dengan popularitas, ketertarikan, waktu, dan sebagainya. Ketiga, hasil dari analisis data alexa.com dapat dijadikan alat evaluasi eksistensi website institusi sebagai dasar pengambilan keputusan terhadap keberaksesan isi (content) website. Demikian sedikit deskripsi penulis mengenai evaluasi via alexa.com untuk optimalisasi keberaksesan website institusi, terutama peningkatan sumber daya perpustakaan sebagai aset informasi yang dapat bermanfaat bagi khazanah kehidupan intelektual masyarakat. 


\section{Daftar pustaka}

Anonim. tt. tj. diakses pada 8 Agustus 2010, dari http://www.alexa.com/siteinfo/iainsalatiga. ac.id.

Pendit, Putu Laxman. 2007. Perpustakaan Digital: Perspektif Perpustakaan Perguruan Tinggi Indonesia. Jakarta: Sagung Seto.

Sutabri. 2005. Sistem Informasi Manajemen, Edisi 1. Yogyakarta: Andi.

Sutarno, N. S.. 2005. Tanggung Jawab Perpustakaan dalam Mengembangkan Masyarakat Informasi. Jakarta: Panta Rei.

Suwarno, Wiji. 2010. Ilmu Perpustakaan dan Kode Etik Pustakawan. Yogyakarta: Arruz Media.

Undang-Undang Nomor 43 Tahun 2007 tentang Perpustakaan.

Webb, Jo \& Powis, Chris. 2004. Teaching Information Skill. London: Face Publishing.

Zorkoczy, Peter. 1999. Information Technology: An Introduction, $3^{\text {th }}$ Edition. London: Pitman Publishing. 